\title{
FROM VIRGIN BUSH TO MATURE GRASSLAND IN TWENTY YEARS
}

\section{H. R. THORP}

\section{Paeroa}

Twenty years may seem a long time, but to an old hand approaching four-score years, it is. not.

On the Coromandel range near Paeroa this development of mature grassland from virgin bush has been accomplished on an area of about 1200 ha of hill country rising from 30 to $500 \mathrm{~m}$ above sea level. Only about $5 \%$ of this country is ploughable but most of it is "riding" country. The rainfall ranges from 1500 to $2500 \mathrm{~mm}$ depending on elevation and is fairly evenly spread over the year. In fact, it is often very difficult to get a burn even in the driest months.

The bush is rain forest, consisting of tawa, hinau, mangeao, kohe and mahoe with a scattering of rimu, miro, matai, totara and a few kauris. The usual tangle of kiki-kiki, supplejack and other vines together with punga and other ferns made up the undergrowth.

This is a brief account of how this country has been transformed into pasture which can carry 6 ewe equivalents to the acre - i.e., 15 e.e. per hectare.

Bush felling was not continuous, nor were blocks of more than SO ha felled in one year and during the slump years and during the war, no bush was felled. From 1924 to 1954 all bush was felled with the axe but from 1954 to 1970 chainsaws were used. Today, all the bush has been felled and we are now half-way through the third 20-year period. Felling has been speeded up over the past 20 years because of the availability of finance and the use of chainsaws. Blocks of about 10 ha were surveyed with prismatic compass so that contractors could be paid frequently.

The bush was felled in winter months and left until the following January when it was burned. The burns were not always good. It was very difficult to get a dry spell long enough and to get a day with the right wind. Until 1956, there was no airstrip on this property and all grass seed and manure was spread by hand and on a bad burn this was very difficult.

In the early days, before topdressing, the seed mixture contained danthonia and browntop. This was necessary because rye- 
grass and white clover disappeared after a few years, When topdressing commenced in 1930, danthonia and browntop were not used, but they filled in places where pasture was thin:

Grass seed was sown in March and by July it was fit to graze and this was when big cattle were used. The first year the pasture was good but it deteriorated from the second to the fourth yeas. This has happened with every block developed up to the present time, in spite of all modern ideas and in spite of the experience gained over the years.

The weeds also encroached in these years. In the first place there was second growth, then fireweed, inkweed and blackberry appeared in profusion, especially where there had been old clearings or open places in the bush. Next was bracken with ring fern on the shady faces and wet places. After a few years' experience, it was found that controlled stocking was the answer. The advent of topdressing improved things considerably but, by itself, could not solve a situation nothing short of disastrous. The final conclusion was that there were three essentials and that these were fencing, stocking and topdressing. No one of these was any good without the other two, but without topdressing a good solid turf could be produced by controlled stocking.

All type's of stock must be used and must be complementary to one another - cattle, sheep and goats in any order, or in the order to suit the conditions. Goats will eat almost anything. Cattle will eat bracken, manuka scrub and second growth. Sheep will eat ragwort, buttercup, docks and most flat weeds and will assist with blackberry and gorse control. Goats will kill blackberry right out and will even have a go at gorse. There are some weeds such as fireweed, inkweed, foxglove and Scotch and Californian thistles which come, then go, and seldom appear again. Barley grass, winged thistle and nodding thistle can be kept out by spraying and by not buying in stock except bulls and rams. It is also helpful to have good neighbours.

The type of stock used for control will depend on the conditions. Not many goats are needed as, even in the worst country, one goat per hectare is sufficient to kill all blackberry and assist in controlling other weeds. Goats can be phased out as the country becomes clean. The ratio of cattle can be varied according to the condition and age of the pasture, but, in the early years of development, the ratio of cattle to other stock has to be as high as 50: 50 .

Now to the first essential, fencing, good fencing, fencing that will control all stock. A well-built seven-barbed wire fence with 
five posts and 25 battens per $20 \mathrm{~m}$ will be sufficient. As stock management is the key to the whole development, paddock size has to be in relation to the area developed. Thus, from a fencing point of view, the larger property becomes more economical. In the case of this property, the paddock sizes progressed from 20 to 40 ha or more and then back to about 30 ha. All fencing had to be related to water, roads and contour. The old story of fences on the ridges and gates and yards on the flats and saddles still applies, but ease of stock movement has to be considered when rotational grazing and mob stocking are carried out and it has been proved on this farm that the secret of success is in this method of farming.

Where possible, rotational grazing is carried out on a 6 or 7 paddock and a weekly shift principle from February to July and set-stocking from July to February. This developed block has now been cut into two farm which is each carrying over 6000 ewe equivalents although much of the areas are still in a fairly raw state, the last 400 ha having been felled out of bush in the last 12 years.

From an economic point of view, the position in the first 10 years seems to be hopeless. In fact, it is hopeless, but with clearings increasing in size the economy improves and the older country helps to keep the development going, until, after 20 years, production values can show a good return on capital. It also gives the owner the satisfaction of creating something out of nothing, something which will remain for ever to the benefit of himself and to the nation.

There are many thousand hectares on the Coromandel Peninsula still in scrub and bush that are capable of being developed in this manner. 